\title{
Trailer Parks as Hotbeds of Crime: Fact or Fiction?
}

\author{
Emmanuel P. Barthe, Matthew C. Leone \& B. Grant Stitt \\ Department of Criminal Justice, University of Nevada \\ Nevada, USA \\ E-mail: mleone@unr.edu
}

Received: October 4, 2014 Accepted: November 3, 2014 Published: November 28, 2014

doi:10.5296/iss.v2i2.6402

URL: http://dx.doi.org/10.5296/iss.v2i2.6402

\begin{abstract}
Studies of how physical environments contribute to crime are both numerous and revered. Relative to these studies is the perception that subsidized public housing (housing reserved for low income residents) has been viewed as being disproportionately criminogenic. Researchers, however, have historically ignored other housing types frequented by low income residents, but not normally subsidized through public programs. This research examined crime frequencies and patterns in both subsidized public housing units and trailer parks, and compared both locations to income-similar residential areas. Findings indicate that trailer parks are not "hotbeds of crime" are actually lower in some types of crime than their subsidized low-income housing counterparts.
\end{abstract}

Keywords: public housing and crime, trailer parks, calls for service, low inco me housing, subsidized housing 


\section{Trailer Parks as Hotbeds of Crime: Fact or Fiction?}

The study of "place" as a criminogenic factor is a central and historically important component of theoretical criminology. While it is difficult to identify exactly when the impact of place on the genesis of crime was first noted, history shows that areas around town centers were frequented by thieves and vagabonds since the development of those town centers in the $16^{\text {th }}$ century (cf. Rose, 1988). These areas were so well known as places of crime that the criminals considered these lands to be their own, and warned those travelling through these places to carry sufficient properties and funds to guarantee safe passage.

In the United States, modern academic interest in the relationship between location and disorder began with the work of Shaw and McKay in Chicago. Building on the earlier Human Ecology work of Park, Burgess, and McKenzie (1925), Clifford Shaw and Henry McKay (1969) utilized concentric zones to study juvenile delinquency in Chicago. This work eventually led to the creation of several theories of social disorganization which were used to explain both adult crime and juvenile delinquency, and defined Shaw and McKay as the originators of what became known as the theory of Social Disorganization (Lilly, Cullen, \& Ball, 2011).

The Social Disorganization perspective emphasized community-level causes of crime, specifically how social factors such as poverty and mobility contribute to the breakdown of formal and informal social controls, leading to lawlessness and criminality (Bellair, 1997; Bursik \& Grasmick, 1993; Sampson, 1985; Sampson, 1987; Sampson \& Groves, 1989; Sampson, Raudenbush, \& Earls, 1997; Sampson \& Wilson, 1995).

A criticism leveled at the Social Disorganization movement involved their concern for issues exclusively related to social disorganization caused by location. It was noted by theorists such as Merton (1938), Cohen (1955), and Cloward and Ohlin (1960), that persons in disorganized areas might desire status goals and material goods, but their access to these goals are structurally blocked. Consequently, access to desirable resources, individual goal orientation, and structural opportunity may not be distributed evenly across the geographic plane of a society, and therefore location might best be considered one of many possible factors which contribute to crime.

More recently, research further refined the study of the geography of crime by incorporating more distinct elements of the environment, such as travel paths, path intersections, and area edges, into spatial frameworks (Brantingham \& Brantingham, 1999). These ideas have gone through several revisions since C. Ray Jeffery's “Crime Prevention Through Environmental Design" (CPTED) was originally published in 1971. Since that time, CPTED has remained a respected construct in crime control, and low income housing has remained an important and readily available location for empirical enquiry.

\section{Low Income Housing and Crime}

In a significant review of criminological research on crime in low income housing, Holtzman noted that "the stereotype that public housing residents are among the poorest Americans is quite accurate" (1996:368), and that residents of public housing in the United States are predominately minorities, with less than 30 percent of low income area residents identifying as White. Further, he noted that census tracts in which public housing developments are 
located are considerably poorer than the nation as a whole and that the major sources of income of the residents of these census tracts are federally provided (pensions, Supplemental Security Income, etc.) or are state welfare based. Households represented in these public housing units are characterized by racial segregation, poverty, welfare dependency, single parenthood, and other aspects of severe disadvantagment (Holtzman, 1996). Significant physical deterioration also plagues many public housing projects, prompting some to label these areas "warehouses for the most disadvantage segments of the urban population" and to argue the environment intensifies the "racial/ethnic segregation and the social isolation of their residents" (McNulty, 2000:707).

While numerous studies have confirmed the relationship between crime and public housing (cf. William Brill and Associates, 1977; Burby \& Rohe, 1989; Dunworth \& Saiger, 1993; Fagan \& Davies, 1997; Farley, 1982; Harrell \& Gouvis, 1994; Holtzman,1996; Holtzman, Kudrick, \& Voytek, 1996; Newman, 1972; Popkin, Gwiasda, \& Olson, 2000; Roncek et. al., 1981), Holtzman (1996) has argued that criminologists have historically lacked the tools to systematically and reliably collect the data necessary to determine whether crime rates in public housing developments differed from those of the immediately surrounding neighborhood. Holtzman proposed using a survey methodology similar to the National Criminal Victimization Survey to measure criminal victimization in these small but well-defined public housing developments. This methodology was utilized by Holtzman and Piper (1998), and while they acknowledged that their findings were not broadly applicable due to their small sample size (510 households) they agreed that the study should be viewed as an attempt to apply more modern research methodologies to these physical areas.

Following the broad acceptance of geographic information systems (GIS), Holtzman, Hyatt, and Kudrick (2005) merged the ideas of the prior study with this new technology, and created what would become a groundbreaking examination of crime in public housing developments. Utilizing GIS technology, Holtzman et al. extracted reported Part I crime incidents from police databases in public housing developments and surrounding neighborhoods. In each of the three cities utilized in this research, Holtzman et al. separated the cities into 1) public housing authority developments, 2) a 300-meter buffer surrounding each of the public housing developments, and 3 ) the parent jurisdiction as a whole. Their results revealed that being the victim of aggravated assault was higher in public housing than in surrounding neighborhoods or in the larger parent jurisdictions. Conversely, they found the risk of property crime victimization for burglary, larceny, and auto theft to be much lower in these public housing developments. They further noted that these 300-meter buffer zones were more dangerous than the parent jurisdictions as a whole. This is because the buffer zones were adjacent to these public housing authority properties, and thereby remained part of the "hot zone", with higher rates of crime than found in the rest of the city. It is logical that areas surrounding crime hot spots have higher crime rates than parent jurisdictions (but less than the hot spot itself) since there a likely spill-over effect from the criminogenic area. Thus, they concluded that the public housing developments could not be "characterized as islands of calm in otherwise rough neighborhoods" (Holtzman, Hyatt, \& Kudrick 2005, p. 325), but rather that their impact on crime began within these housing units and diminished as the distance from these areas increased. 


\section{Trailer Parks and Crime}

Trailer parks are designated residential areas that consist of ind ividual land lots equipped with electrical, water, and sewer hookups, which allow persons with mobile living units, such as trailers or motor homes, to connect to these utilities and reside there affordably and for extended periods of time. Such living situations are often inexpensive because the motor home or trailer is usually wholly owned; therefore the only cost for residing in these locations is the nominal space fee and utilities.

According to the 2011 American Housing Survey, the median monthly housing cost for a site-built home was $\$ 1,340$, in contrast to $\$ 545$ for a manufactured home (U.S. Census Bureau, 2011). This cost differential suggests that mobile or pre-manufactured homes are an affordable alternative to conventional home ownership. Because of this economic reality, trailer parks have inherited the reputation of being de facto low income housing, inhabited mostly by poor and disenfranchised individuals. While trailer parks were originally designed to offer a temporary housing location to residents and their mobile living units, many of these parks have witnessed these trailers slowly become permanent park fixtures. The "mobile" nature of many of these trailers is symbolic rather than practical, and after years or decades of stasis, many of these once mobile units would be virtually impossible to move.

Popular culture has also reflected the reputation of trailer parks and their residents, with such televised shows and stage productions such as "Trailer Park Boys", "My Name is Earl", and "The Great American Trailer Trash Musical". These entertainment oriented creations depicted the residents of these housing sites as vulgar, uneducated, poor, and potentially dangerous individuals. Culturally popular terms such as "trailer trash" serve to reify such beliefs about the residents of these trailer parks. This, of course, is a stereotypic depiction of trailer parks and their residents, and it must be acknowledged that there are well maintained and regulated trailer parks where residents benefit from a well-designed, attractively landscaped, safe and affordable living environment. Furthermore, innovations in manufacturing have also allowed mobile home owners to enjoy much larger and more comfortable homes than in the past. In short, not all trailer parks are equal; some may be hot spots of criminality and deviance, while others provide their residents with quality, affordable housing. While many of these residents own their living spaces, by not being responsible for the property or the infrastructure of the park, the problems and expenses common to traditional home ownership are greatly reduced. Social disorganization theory supports idea that those residing in public or low-income housing are traditionally more of a problem for law enforcement agencies and the surrounding neighborhoods (Holtzman, et al., 2005; Mazerolle et al., 2000). Place-based theories of crime, such as routine activity theory (Cohen \& Felson, 1979; Eck \& Weisburd, 1995; Cornish \& Clarke, 1986) would support the idea that low income housing would have higher crime rates than private residential housing since the lack of ownership might result in the residents caring less or being less vigilant with their surroundings, allowing disorder to both originate and persist. This relationship between income and disorder, however, becomes much less clear when one considers the many different types of low income housing. One could argue that the transient nature of mobile home parks could make them more conducive to crime and disorder, while another line of reasoning could argue that the environmental factors specific to trailer parks, such as the close proximity of trailers in the park, may 
actually reduce disorder.

Studies which specifically examine crime patterns in mobile home/trailer parks are $r$ are, and exist primarily in practitioner-oriented publications which focus on park management and operations. These often non-peer reviewed publications have documented the crime problems associated with certain mobile home communities, and have also chronicled attempts by local law enforcement agencies to institute programs to combat these problems (Dominguez, 2003; Farley, 1992). Other sources examined specific criminal behaviors in unique trailer park environments, such as "How to Spot Crime in a Trailer Park" (Reynolds, 2008) and "Drugs and Crime Plague FEMA Trailer Park Residents" (Lohr, 2006). These documents may serve to further reinforce the perception of crime and disorder in trailer parks. As Salamon and MacTavish (2005) noted, residents of towns near rural trailer parks tended to blame park residents for local crimes and considered the residents "freeloaders" for supposedly not paying their fair share of property taxes for education and other public services. While there is a relatively little research on crimes in trailer parks, there are even fewer studies on crimes committed by trailer park residents in other locations. For example, do trailer park residents travel often to commit crimes in remote locations? And if so, how far do they travel? It is important to note that trailer parks are usually located on the outskirts of a jurisdiction, and residents without the means to travel long distances will have limited opportunities to access to other parts of the jurisdiction for the purposes of crime commission. It could also be asserted that trailer parks resemble small communities, and routine activities theory posits that most people remain proximal to their "living" areas, both out of convenience and the unease caused by visiting unfamiliar regions.

\section{Research Question}

Using data provided by law enforcement agencies, the present research will examine the nature and extent of crime found in and around mobile home parks and subsidized housing units. As Holtzman (1996) demonstrated, public housing structures engender certain crime and disorder problems, correspondingly, this research seeks to determine if similar problems exist in trailer parks and their surrounding areas. These analyses seek to answer two specific questions: what is the relative extent of criminality in and around the trailer park environment, and how do these environments compare with other housing sites in the same city? Past research has typically focused upon public housing structures which resemble massive, multi-storied buildings and house thousands of residents in each complex (Holtzman, 1996; Mazerolle, Ready, Terrill, \& Waring, 2000). In contrast, this research will examine smaller low income housing sites and compare them to both the aforementioned mobile home/trailer parks, and selected traditional single-family housing areas using GIS maps to select the data, analyses of variance to compare the areas in question, and t-tests to compare specific offense types across areas.

\section{Methodology}

\subsection{Data Sources}

Calls for service and incidents recorded by the police from 2003 to 2006 were obtained from the planning unit of the municipal police department in the city under examination. An acknowledged limitation of using calls for service as a determiner of crime is that these calls 


\section{Macrothink Institute ${ }^{\mathrm{TM}}$}

are citizen-initiated, meaning some crimes will occur without generating a call for service, sometimes the actual crime detected by officers may be dramatically different than the description of the incident provided by the caller, and sometimes officers will respond but will find no evidence of wrongdoing (Klinger \& Bridges, 1997). Proponents of calls for service as a source of data argue that police underreport incidents that are handled informally. Crime incident reports may represent an "officer orientation", while calls for service will represent the perspective of the citizens of that specific area (Katz et al., 2001). For example, numerous concerned residents can call the police and complain about a noisy corner where youth congregate. These multiple calls for service can be used as both an indicator of the presence of a problem, and a measure of magnitude of the problem. Relying on crime incident data in this case would minimize the severity of the problem, as police may not file a report for an informal action taken to rectify the problem (the noisy youths are asked to go home). Furthermore, a crime report or an arrest will be represented as a single incident, even though a multitude of resident complaints preceded the arrival of the officers and prompted the resolution. The discretionary nature of police work affects what crimes are reported and how they are officially recorded. Sherman et al. assert that "calls for service to the police provide the most extensive and faithful account of what the public tells the police about crime" (Sherman et al. 1989, p. 36).

Data from police call-codes were collected and recoded into calls for service and incident type. Non-crime related calls and incidents, administrative calls, animal related incidents, and lost property were excluded from the database; only incidents dealing with crime and disorder were retained and recoded into the following discreet categories:

1) Violent / Person Crimes

Includes any incident that involved violence or the threat of violence. The person crimes category therefore included all assaults, batteries, sexual crimes, threats, etc.

2) Property Crimes

Includes thefts, vandalism, destruction of property, etc.

3) Public Order Crimes

Includes items like public intoxication, disturbing the peace, noise complaints, lewdness, street racing, etc.

4) Family Disputes

Any event that involved a family disturbance without actual physical violence

5) Burglary (Residential)

Burglaries of residential dwellings

6) Drugs and Alcohol 
Any instance involving the sale, possession, distribution, and manufacturing of drugs or alcohol

7) Car Crimes (thefts of and thefts from)

Burglaries and thefts involving automobiles and motorcycles.

\subsection{Selection of Low Income Housing Sites (Trailer Parks and Public Housing)}

The western United States city where this research was conducted has no large public housing complexes characterized by tall, industrial, and usually neglected buildings. In this particular jurisdiction, there are 750 subsidized residential apartments across eight housing units. Each building unit consists one or two story condominium-type apartments, with six to ten individual dwelling units per building. These housing sites are limited to low income residents, and each site has landscaping, public playgrounds, and other shared public areas that are well maintained. In addition to these public housing sites, there are also apartment complexes that provide subsidized housing for select tenants using the "section 8 " program. These "integrated" apartment complexes were originally designed to welcome low income tenants and more affluent ones, but over time, the majority of tenants became low income families. While these privately owned apartment complexes do not fall directly under the control of the public housing authorities who manage the state owned units, they are de facto low income housing units and are will be used as part of the low income housing areas which will be compared to the trailer park sites.

A list of housing sites where low-income subsidized residents were welcome was collected from the city's housing authority. This list included housing for low-income families, low-income seniors, the disabled, and low-income singles without children. Fifty-one subsidized housing sites were identified, with 53 percent housing families, 31 percent housing seniors and disabled residents, 11 percent housing single individuals, and 5 percent housing unidentified low income residents.

A search using on-line and telephone book sources was then used to identify the trailer/mobile home parks located in the city. Trailer parks were defined as commercial sites that accommodate mobile homes, trailers, and other vehicles for the purposes of providing temporary housing. Not included under this designation were individ ual property owners who agreed to allow an individual to reside on their property in a mobile housing unit, or traditional "camper" oriented campgrounds. Residents of these campgrounds tend to have permanent housing in other communities and utilize these spaces during their brief travels through an area. As such, campground residents tend to be much more transient and less attached to the local community. Available information on some of these sites was sometimes ambiguous and did not clearly indicate if it was a long term location or a more "camping" style facility. In order to avoid including these camping oriented sites, a subsequent physical examination was carried out on all of the trailer parks located within city boundaries, and those temporary camping facilities were then excluded from the analyses reducing the number of verified low-income trailer park facilities to 26 .

Using the satellite imagery program Google Earth, the trailer parks and housing sites were 


\section{Ml Macrothink}

Issues in Social Science

ISSN 2329-521X

2014, Vol. 2, No. 2

located using their business addresses. Geographic boundaries of both subsidized housing sites and trailer parks were then drawn onto the city street layers using ArcGIS, allowing the researchers to create unique polygons for each site.

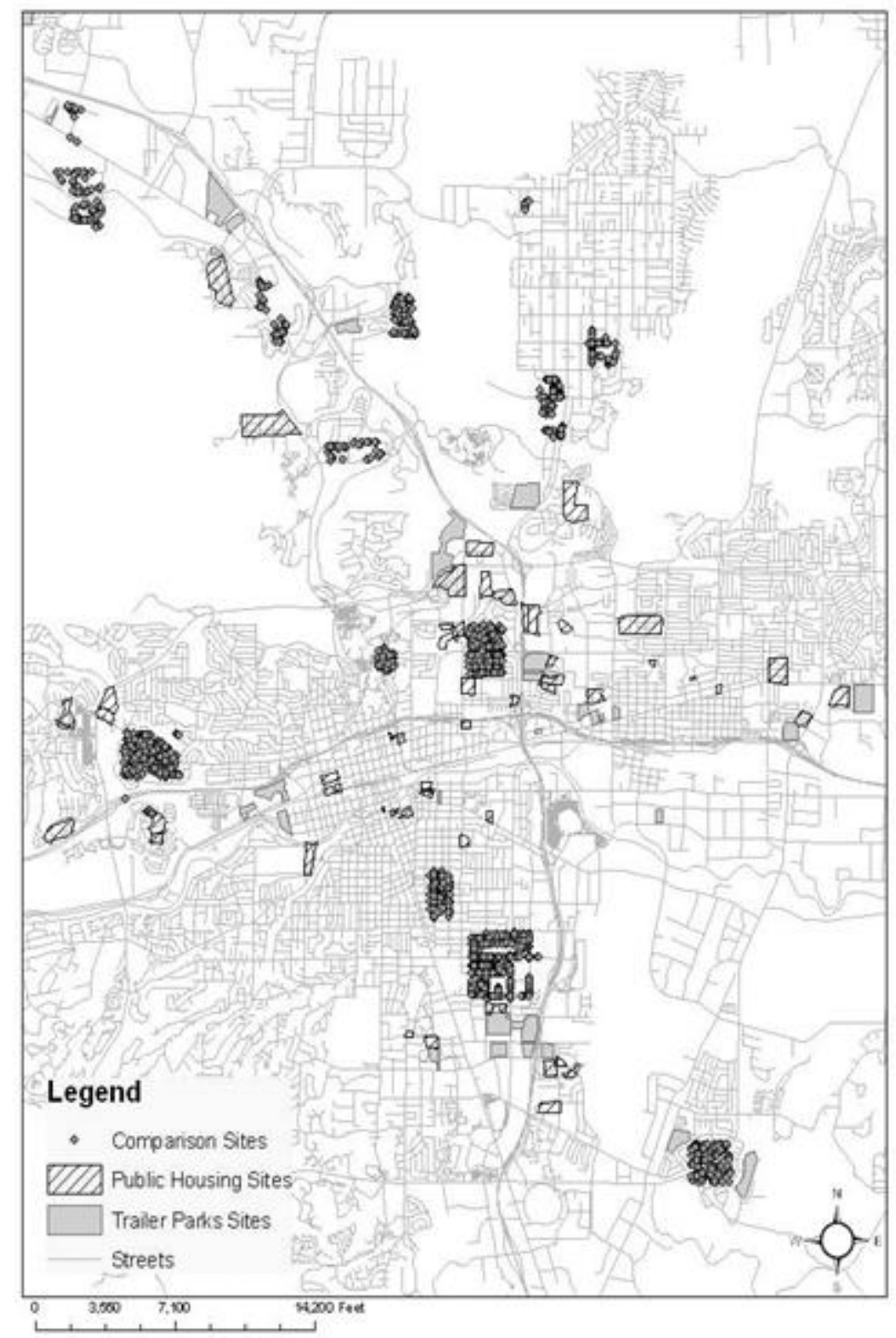

Figure 1. Location of low income housing

Following the creation of the polygons for each of these housing sites, 300 feet buffer areas surrounding each of the housing polygons were again created using ArcGIS (Holtzman, 1996). In all cases, adjacent streets, and streets inside the complexes were also selected, but proximal areas separated by natural boundaries such as highways or waterways were not included in these polygons (see Figure 1). This procedure provided more realistic geographic areas which could be identified as true public housing zones, and allowed for more accurate 
inclusion of crimes occurring in the housing areas and in these adjacent buffer zones.

The data files provided by the police departments included both addresses and map coordinates for each call and each incident report. Using these map coordinates reduced the geocoding errors which typically result from using street addresses in geographic analyses. Using ArcGis, calls for service and crime incidents were then plotted to both the street layer within the housing area as well as these newly created buffer zones surrounding these housing sites.

\subsection{Selection of Low Income Housing Sites (Comparison Areas)}

Comparison areas were then identified. Data provided by the United States Census Bureau were merged with the city's census tracts and block groups, and mean per capita salaries were calculated for each block group containing a trailer park or public housing site. Comparable blocks without trailer parks or other public housing units were then identified, and individual residences were randomly selected from each of these block groups and combined to form these comparison sites. Mean per capita salaries were then calculated for each of these smaller groupings to ascertain if they were still comparable to the selected subsidized low-income housing sites. These groupings were found to be roughly equivalent with the salary estimates for the low income housing sites being $\$ 15,194 ; \$ 17,878$ for the trailer park sites, and $\$ 17,403$ for the comparison residential housing areas. With these relatively similar low income areas identified and mapped, it was then possible to conduct a comparison of crime type and prevalence among these three types of housing. To reiterate, the three sites were: 1) mobile home residences located within trailer parks, 2) apartments within apartment complexes containing subsidized public housing, and 3) individual private residences located in financially disadvantaged neighborhoods. For the purposes of clarity, the state subsidized apartment complexes will be referred to as "public housing", properties which house mobile homes, trailers, or other similar structures will be referred to as "trailer parks", and the residential areas selected as statistical controls will be referred to as "comparison areas".

\subsection{Rate Calculation}

In order to calculate rates per household across the different housing sites, the number of households in each setting was used because it provided a more stable and more reliable measure than population. Facility managers could accurately report how many spaces or apartments were located within their park or complex, and they were able to provide data indicating the presence of spaces or dwelling units that appeared available, but were not available for rental purposes. Therefore, the total number of households was calculated by simply counting the number of available and occupied spaces or living units in both the trailer parks and the public housing sites. Individual residential addresses were, however, used in the comparison areas. Using census and jurisdictional maps, 2,341 residential households were selected from twenty-three different neighborhoods found in comparable block groups (based on mean salary and population density). Number of calls for service and incidents were again calculated for each of those 2,341 locations. A summary of the number of sites and number of households by type of site is presented in Table 1. 
Table 1. Housing site and corresponding number of households

\begin{tabular}{lll}
\hline Site Type & Number & Total Households \\
\hline Trailer Parks & 26 & 3088 \\
Public Housing Sites & 51 & 6016 \\
Comparison Residential Sites & 23 & 2341 \\
\hline
\end{tabular}

\section{Results}

\subsection{Calls for Service}

Calls for service to the police were relatively similar in nature across the three sites over the three-year period. For example, family disputes comprised 23 percent of the calls for service in the public housing sites and 22 percent of the calls in the trailer park sites, while the comparison sites reported only 16 percent. Calls for service for public order crimes comprised 32 percent of all calls at the public housing sites, 32 percent at the trailer park sites, and 34 percent of calls at the comparison sites.

Table 2. Calls for service by housing type

\begin{tabular}{|c|c|c|c|c|c|c|c|c|c|}
\hline \multirow[t]{2}{*}{$\begin{array}{l}\text { Calls } \\
\text { Service } \\
\end{array}$} & \multicolumn{3}{|c|}{$\begin{array}{l}\text { Housing } \\
\text { Sites }(n=6016)\end{array}$} & \multicolumn{3}{|c|}{$\begin{array}{l}\text { Trailer Park } \\
\text { Sites }(n=3088)\end{array}$} & \multicolumn{3}{|c|}{$\begin{array}{l}\text { Comparison } \\
\text { Sites }(n=2341)\end{array}$} \\
\hline & Count & Percent & Rate* & Count & Percent & Rate* & Count & $\begin{array}{l}\text { Perce } \\
\text { nt }\end{array}$ & Rate* \\
\hline Violent Crime & 2158 & 13 & .36 & 939 & 11 & .30 & 1439 & 14 & .61 \\
\hline $\begin{array}{l}\text { Property } \\
\text { Crime }\end{array}$ & 1825 & 11 & .30 & 1187 & 13 & .38 & 1376 & 13 & .59 \\
\hline Public Order & 5165 & 32 & .86 & 2829 & 32 & .92 & 3546 & 34 & 1.51 \\
\hline $\begin{array}{l}\text { Family } \\
\text { Dispute }\end{array}$ & 3677 & 23 & .61 & 1967 & 22 & .64 & 1655 & 16 & .71 \\
\hline Burglary & 630 & 4 & .10 & 357 & 4 & .12 & 399 & 4 & .17 \\
\hline Drugs/Alcohol & 498 & 3 & .08 & 288 & 3 & .01 & 473 & 5 & .20 \\
\hline Car Crime & 1765 & 11 & .29 & 1032 & 12 & .33 & 1260 & 12 & .54 \\
\hline Total & 15718 & 100 & 2.61 & 8599 & 100 & 2.78 & 10148 & 100 & 4.33 \\
\hline
\end{tabular}

(*Rate is rate per household)

Findings were similar for individual call types (see Table 2). Trailer park sites showed the lowest rate of violent crime calls for service at .30 per household. In contrast, the public housing sites' rate per household was .36 and the comparison sites reported a rate of .61 per household respectively. When considering all calls for service made to the police, the public housing sites had the lowest rate per household at 2.61, followed by the trailer parks at 2.78 . In contrast, the comparison site rate was substantially higher at 4.33 .

These differences, while interesting and informative, were only descriptive in nature. In order 


\section{Macrothink}

to ascertain the statistical significance of these differences, Analyses of Variance (ANOVA) were utilized. Monthly rates per one-hundred households for the three main call categories (violent, property, and public order) were calculated for each of the three housing types were compared using ANOVA. Significant differences across these calls for service categories for the three types of housing sites were noted, and as Table 3 demonstrates, the comparison sites had consistently higher mean monthly rates for all call types. Table 3 does show, however, that the mean monthly call rate is higher for those households located in trailer parks than those located in public housing sites. To further calculate the differences between trailer parks and public housing sites, the mean monthly rate for calls for service was compared across more specific call types using t-tests. As Table 4 shows, there were significant differences across all call types with the greatest difference being in the monthly rate per household of family disputes (5.3 in trailer parks versus 2.3 in public housing). While still statistically significant, the difference between the other call for service types was less striking.

Table 3. Call rates by housing type for three main crime types

\begin{tabular}{llll}
\hline Calls for Service & Trailer Parks & Public Housing & Comparison Site \\
\hline Violent Crime $*$ & 2.5 & 2.0 & 5.1 \\
Property Crime $*$ & 3.2 & 1.9 & 4.9 \\
Public Order* & 7.6 & 4.9 & 12.6 \\
\hline
\end{tabular}

* Significant difference at $\mathrm{P}<.05$.

Table 4. Monthly call rates by low income housing

\begin{tabular}{lll}
\hline Calls for Service & Trailer Parks & Public Housing \\
\hline Family Dispute* $^{*}$ & 5.3 & 2.3 \\
Car Crime* & 2.8 & 1.7 \\
Burglary* & 1.0 & 0.6 \\
Drugs/Alcohol* & 0.8 & 0.7 \\
\hline
\end{tabular}

* Significant difference at $\mathrm{P}<.05$.

\subsection{Incidents}

As noted above, crime incidents represent a different type of data than calls for service in that incidents represent actual crime occurrences that were recorded by police by means of a police report. Analyses of incidents reported by the police display a similar pattern to the calls for service data. While there are some slight differences across crime types for each site, all three sites demonstrate that their biggest problems revolve around family disputes, property crimes, and car crimes (please see Table 5). For example, in the public housing sites, the three most prevalent crimes were family disputes ( 23 percent), property crimes ( 22 percent), and car crimes (20 percent). In the trailer park sites, these were property crimes (23 percent), family disputes (19 percent), and car crimes (16 percent). In the comparison sites, the three most common crimes were property crimes (27 percent), car crimes (19 percent), and family disputes (13 percent). In contrast to those crimes, offenses against public order offered some unique findings. While conventional wisdom would predict that public order offenses would 
be higher in the public housing and trailer parks sites due to the population density, transient populations, etc., Table 5 shows that the comparison site has the highest rates per household for public order crimes (and all other crime types for that matter) when compared to the other two low income housing sites.

Table 5. Crime incidents by housing type

\begin{tabular}{|c|c|c|c|c|c|c|c|c|c|}
\hline \multirow[t]{2}{*}{ Crime Type } & \multicolumn{3}{|c|}{$\begin{array}{l}\text { Housing } \\
\text { Sites }(n=6016)\end{array}$} & \multicolumn{3}{|c|}{$\begin{array}{l}\text { Trailer Park } \\
\text { Sites }(n=3088)\end{array}$} & \multicolumn{3}{|c|}{$\begin{array}{l}\text { Comparison } \\
\text { Sites }(n=2341)\end{array}$} \\
\hline & Count & $\begin{array}{l}\text { Perce } \\
\text { nt }\end{array}$ & Rate & Count & Percent & Rate & Count & Percent & Rate \\
\hline Violent Crime & 101 & 15 & 0.02 & 251 & 13 & 0.08 & 270 & 11 & 0.12 \\
\hline $\begin{array}{l}\text { Property } \\
\text { Crime }\end{array}$ & 147 & 22 & 0.02 & 448 & 23 & 0.15 & 646 & 27 & 0.28 \\
\hline Public Order & 40 & 6 & 0.01 & 130 & 7 & 0.04 & 137 & 6 & 0.06 \\
\hline Family & 159 & 23 & 0.03 & 373 & 19 & 0.12 & 310 & 13 & 0.13 \\
\hline Dispute & & & & & & & & & \\
\hline Car Crime & 140 & 20 & 0.02 & 316 & 16 & 0.10 & 455 & 19 & 0.19 \\
\hline Burglary & 52 & 8 & 0.01 & 152 & 8 & 0.05 & 198 & 8 & 0.08 \\
\hline Drugs/Alcohol & 19 & 3 & 0.00 & 161 & 8 & 0.05 & 285 & 12 & 0.12 \\
\hline Total & 658 & 100 & .11 & 1831 & 100 & .60 & 2301 & 100 & .99 \\
\hline
\end{tabular}

Table 6. Monthly incident rates by housing type

\begin{tabular}{llll}
\hline Crime Type & Trailer Parks & Public Housing & Comparison Site \\
\hline Violent Crime $*$ & .68 & .14 & .96 \\
Property Crime $*$ & 1.21 & .20 & 1.30 \\
Public Order* & .35 & .06 & .49 \\
\hline
\end{tabular}

* Significant difference at $\mathrm{P}<.05$.

To test for statistical significance across housing types, an ANOVA was then performed on the incident data. These analyses indicated that differences across the sites were statistically significant for violent, property and public order crime categories. Table 6 shows that, once again, the comparison residential sites had the highest rates per household across crime types when compared to the other housing sites, but also that trailer parks had higher rates than the public housing sites.

\subsection{Trailer Park Calls for Service Analysis}

The above rates were aggregated for all the sites within each housing category, making necessary a further exploration of the variation among trailer parks to shed additional light on this particular type of low-income housing. Call for service rates were calculated (\# of total calls / \# of households per park) for each trailer park. This generated a rate for each park, and 
the parks were then ranked from highest to lowest based upon this score (ranging from a low of .17 to a high of 13.43 , with a mean of 2.85). Of the twenty-six trailer parks included in this research, seventeen $(65 \%)$ fell below the trailer park mean call rate, indicating that the majority of the trailer parks examined did not generate significant crime problems for the city and the average was skwewed by the presence of a few problematic locations. Three of the trailer parks examined had unusually high call rates. These top three trailer parks (named Trailer Park A, B, and C) were first examined individually, and then compared across the different call types. As Table 7 shows, Trailer Park B had an especially high rate of public order crime calls for service (4.3) when compared to the other two sites (A and C). Table 7 also demonstrates that there were significant variations across trailer parks for certain call types. For example, family disputes made up 26 percent of the calls in Trailer Park A, 13 percent in Trailer Park B, but only 7 percent in Trailer Park C. Conversely, Trailer Park B had a rate of 3.5 for car crimes compared to .4 and .9 in the other trailer parks. These findings support the idea that there are a few parks that distinguish themselves through significantly higher call rates, but these "top offenders" differed substantially in the types of calls of service they produced.

Table 7. Calls for service for the three top trailer parks

\begin{tabular}{llllllllll}
\hline $\begin{array}{l}\text { Calls } \\
\text { Service }\end{array}$ & for & Trailer Park A & \multicolumn{3}{c}{ Trailer } & Park B & \multicolumn{5}{c}{ Trailer Park C } \\
\hline & & & & & & & & \\
Violent Crime & 46 & 13 & 1.0 & 129 & 11 & 1.4 & 59 & 14 & 1.0 \\
Property Crime & 39 & 13 & .9 & 121 & 10 & 1.3 & 85 & 20 & 1.4 \\
Public Order & 79 & 27 & 1.8 & 388 & 32 & 4.3 & 131 & 31 & 2.1 \\
Family Dispute & 77 & 26 & 1.7 & 153 & 13 & 1.7 & 31 & 7 & .05 \\
Car Crime & 16 & 5 & .4 & 315 & 26 & 3.5 & 58 & 14 & .9 \\
Burglary & 8 & 3 & .2 & 23 & 2 & .3 & 2 & 0 & 0.0 \\
Drugs/Alcohol & 19 & 7 & .4 & 47 & 4 & .5 & 43 & 10 & .7 \\
\hline
\end{tabular}

\subsection{Trailer Park Incident Analysis}

Incident rates were also compared across the twenty-six trailer parks to ascertain the degree of cross-park variation. Again, seventeen of the trailer parks examined (65\%) had rates below the average trailer park incident rate of .63 , also indicating that the majority of trailer parks were not criminogenic. Similar to the calls for service analyses, the same three trailer parks with the highest incident rates were selected for additional examination (see Table 8 for offense percentages). 
Table 8. Offense Types for the Trailer Parks with the Highest Crime Rates (in percent)

\begin{tabular}{llll}
\hline Crime Type & Trailer Park A & Trailer Park B & Trailer Park C \\
\hline Violent Crime & 13 & 10 & 11 \\
Property Crime & 36 & 21 & 23 \\
Public Order & 3 & 8 & 4 \\
Family Dispute & 7 & 15 & 21 \\
Car Crime & 16 & 25 & 8 \\
Drugs/Alcohol & 17 & 8 & 18 \\
Other Crime & 8 & 13 & 15 \\
Total & 100 & 100 & 100 \\
\hline
\end{tabular}

Drug and alcohol percentages were much higher in two of the three sites (A \& $\mathrm{C}$ ), with site $\mathrm{A}$ showing $17 \%$, site $\mathrm{C}$ showing $18 \%$. In comparison, alcohol and drugs made up only $8 \%$ of the total incidents for site $\mathrm{B}$. Site $\mathrm{C}$ also has a large percentage of family disputes when compared to the other two sites. Further, there were variations among the sites for the percentage of car-related crimes, indicating that even among the three sites with the highest rate of offenses, there were still substantial differences in criminal activities.

\section{Discussion}

This research examined crime generation related to two types of low-income housing: Subsidized Public Housing and Trailer Parks. Overall, the public housing sites and the trailer park sites did not create significant crime problems when compared to their residential counterparts, and only a few trailer parks were associated with high call for service and crime incident levels.

There is a social perception that all public housing resembles the towering and gloomy "housing projects" found in many large cities. In reality, most small and medium size jurisdictions offer subsidized public housing that in no way resembles these larger city counterparts. The low-income public housing sites examined in this research were not structurally different than the majority of public housing found across the United States. These sites ranged from one to three stories, with only a few exceeding that height. In terms of geographic placement, both types of sites were dispersed across the cityscape, and were not exclusively located in what was considered the "slum" area within the city. In most public housing sites, residents have direct access to the exterior parking lot, reducing the need for elevators, lobbies, hallways, staircases, or other common areas that have been shown to facilitate vandalism, victimization, and other forms of criminality (Mazerolle, et. al., 2000). The trailer parks, while equal in population density, shared similar characteristics (single story units, direct access to parking spaces, individual entry to residence, and few common spaces for victimization).

This research found that the economically comparable low income residential housing sites produced more calls to the police and more crime incidents than the public housing sites or the trailer parks. Overall, trailer parks did generate more crime than the other public housing 
sites examined, but this was due to the influence of the few parks which were responsible for the majority of the incidents and calls. The majority of trailer parks were in fact relatively peaceful law-abiding residential communities. These lower than expected crime problems in trailer parks could be due to several reasons.

From a socio-economic standpoint, trailer park residents, due to their reduced cost of living, may have more surplus income and consequently there may be less economic motivation to commit crime. Furthermore, tenants may feel compelled to maintain the peace as their housing options are limited, and an eviction would require moving their mobile housing unit to another park, a difficult, time consuming, and expensive endeavor. Another possibility is that some tenants of the trailer parks choose to not call the police as often as other residents because they fear retaliation from neighbors, or because they do not want to attract police attention. It is also possible that these trailer park residents are accustomed to such living conditions, and consider it normal and unworthy of police intervention. Although these are viable points, there may be more compelling explanations for this lack of rampant crime and disorder in trailer parks. Borrowing from Poyner and Webb (1991), Felson offers some practical insight. The impact of ownership may be an important factor in these findings as trailer park residents generally own their dwelling, and "if you own your own property, you have good reason to keep it clean, safe, secure, and valuable" (Felson, 1998, p. 28). Therefore, while less valuable than traditional houses, trailers still represent a form of equitable ownership, engendering certain protection measures such as informal surveillance, alarm systems, and place maintenance. Additionally, there are often central offices for residents' needs and to help coordinate other maintenance items (i.e., regulating water usage, tree cutting, snow removal, maintaining resident logs, etc.). As such, these trailer park offices provide an important function as "place managers" (Eck, \& Weisburd, 1995; Green, 1995; Sherman \& Weisburd, 1995; Weisburd \& Green (1995), providing residents with park rules, enforcing traffic and parking regulations, and ensuring that disorderly behaviors are kept to a minimum.

Another trailer park attribute that may diminish crime is the proximity to neighboring trailers, which may have crime reducing properties. As Felson noted, designing housing layouts to create "sight lines" which allow neighbors to have a direct view of the nearby homes is invaluable in reducing property crime (Felson, 1998). Close housing proximity creates a community of guardians, making illegal activity much easier to detect (see Figure 2), and may also increase informal social control and decrease reliance on formal interventions. Finally, trailer parks do not have environmental features such elevators, rooftops, or dark alleys, all of which traditionally facilitate crime in low income housing venues. 


\section{$\Lambda$ Macrothink}

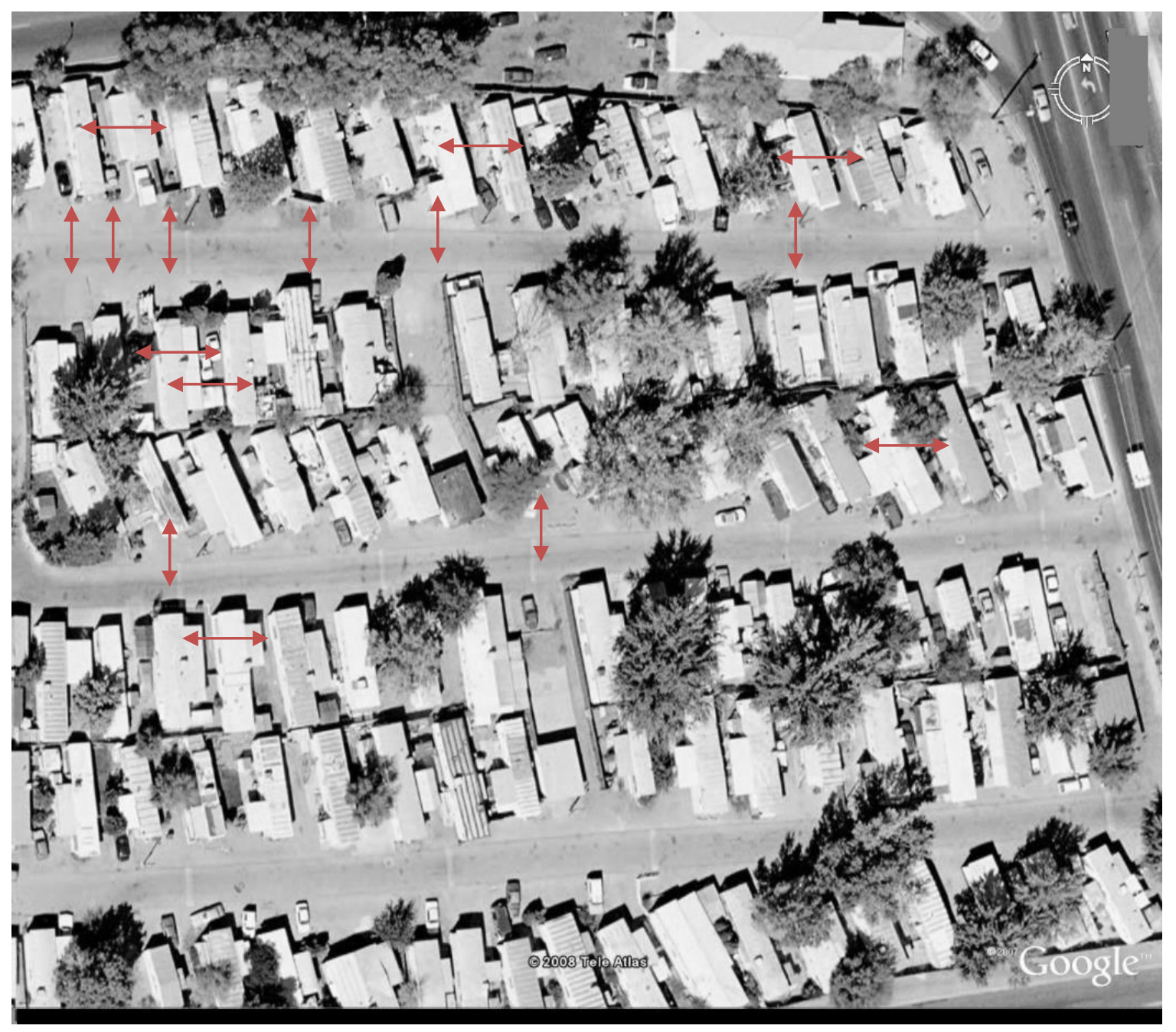

Figure 2. Layout of a traditional trailer park showing trailer proximity and some sample corresponding "sight lines"

\section{Conclusion}

Clearly more research is needed to truly understand the different dynamics that factor into crime prevalence in the types of housing sites examined. In terms of trailer parks, other factors such as the number of owners versus renters, the average rental time for those residents who rent rather than own, the percentage of children in the park, and the average cost of the trailers are all variables which should be examined in future studies. Additionally, the percentage of subsidized units in the low-income complexes, as well as the transiency, population density, and other demographic information of the residents of these housing sites were not considered for this analysis, but should be included in future research. The economic condition of the residents of each of these sites should also be examined and included in future studies. As was noted earlier in this paper, single family detached homes are much more expensive than subsidized housing and trailer park dwellings. Therefore, it is appropriate to question if the measured income similarities used to create comparison groups 
actually create surplus income dissimilarities. In reality, do those who live in trailer parks and subsidized housing have more discretionary income and therefore a diminished economic incentive to commit crimes of gain? Further examinations of the real cost of residing in these areas could create a better understanding of the expenses associated with each of these living areas.

The crime incident and calls for service differences among the three most problematic trailer parks should also be examined more completely. It is likely that there are social or structural factors that engendered the specific problems each of these locations experienced. A more complete evaluation of these predisposing elements could lead to both a better understanding of crime genesis, and an increased probability of crime control for those most at-risk locations. Crime genesis as a result of physical place is both complex and complicated, and the addition of these and other variables could help to refine the study of "place" as a criminogenic factor in many areas of environmental criminology.

\section{References}

Bellair, P. E. (1997). Social interaction and community crime: examining the importance of neighbor networks. Criminology, 35, 677-703. http://dx.doi.org/10.1111/j.1745 -9125.1997.tb01235.x

Brantingham, P. L., \& Brantingham, P. J. (1999). A theoretical model of crime hot spot generation. Studies on Crime and Crime Prevention, 8, 7-26.

Burby, R. J., \& Rohe, W. M. (1989). Deconcentration of public housing: effects of residents' satisfaction with their living environments and their fear of crime. Urban Affairs Quarterly, 25, 117-141. http://dx.doi.org/10.1177/004208168902500108

Bursik, R. J. Jr., \& Grasmick, H. G. (1993). Neighborhoods and crime: the dimensions of effective community control. Lexington. http://dx.doi.org/10.1086/230438

Cloward, R., \& Ohlin, L. (1960). Delinquency and Opportunity. NY: Free Press.

Cohen, A. (1955). Delinquent Boys. NY: Free Press.

Cohen, L. E., \& Felson, M. (1979). Social change and crime trends: A routine activity approach. American Sociological Review, 44, 588-608. http://dx.doi.org/10.2307/2094589

Cornish, D., \& Clarke, R.V. (1986). The Reasoning Criminal: Rational Choice Perspective on Offending. New York, NY: Springer-Verlag. http $/ / d x . d o i . o r g / 10.1007 / 978-1-4613-8625-4$

Dominguez, L.G. (2003). Integrity and Partnership Take Hold... and Transform a Community. Sheriff, 55, 42-43.

Dunworth, T., \& Saiger, A. (1993). Drugs and crime in public housing: a three-city analysis. Santa Monica, CA: Rand. http://dx.doi.org/10.3886/ICPSR06235.v1

Eck, J., \& Weisburd, D. (1995). Crime and place: crime prevention studies (4th ed.). Monsey, NY: Willow Tree Press. 
Fagan, J., \& Davies, G. (1997). Crime in public housing: two-way diffusion effects in surrounding neighborhoods. Paper presented at the Workshop on Spatial Analysis of Criminal Justice Data. City University of New York Graduate Center. http://dx.doi.org $/ 10.4135 / 9781452220369$

Farley, J. E. (1982). Has public housing gotten a bum rap? The incidence of crime in St. Louis public housing developments. Environment and Behavior, 14, 443-477. http://dx.doi.org/10.1177/0013916582144004

Farley, Sgt. B. (1992). Focusing crime and disorder in mobile home parks. Problem Solving Quarterly, 5, 1-2.

Felson, M. (1998). Crime and Every Day Life. Pine Forge Press: Thousand Oaks, CA.

Green, L. (1995). Cleaning up drug hotspots in Oakland California: the displacement and diffusion effects, Justice Quarterly 12, 737-754. http://dx.doi.org/10.1080 /07418829500096271

Harrell, A., \& C. Gouvis. (1994). Predicting neighborhood risk of crime. Washington, DC: The Urban Institute.

Holtzman, H. R. (1996). Criminological research on public housing: toward a better understanding of people, places and spaces. Crime \& Delinquency, 42, 361-378. http://dx.doi.org/10.1177/0022427896033003004

Holtzman, H. R., \& Piper, L. (1998). Measuring crime in public housing: methodological issues and research strategies. Journal of Quantitative Criminology, 14, 331-351. http://dx.doi.org/10.1023/a:1023057120475

Holtzman, H. R., Hyatt, R. A., \& Kudrick, T. R. (2005). Measuring crime in and around public housing using GIS. In F. Wang (Ed.), Geographic information systems and crime analysis (pp. 311-329). Hershey, pa: idea group publisher. http://dx.doi.org/10.4018 1978-1-59140-453-8

Holtzman, H. R., Kudrick, T.R., \& Voytek, K. P. (1996). Revisiting the relationship between crime and architectural design: an analysis of data from HUD's 1994 survey of public housing residents. Cityscape: A Journal of Policy and Development and Research, 2, 107-126.

Jeffery, C. R. (1971). Crime prevention through environmental design. Beverly Hills, CA: Sage Publications. http//dx.doi.org/10.1177/000276427101400409

Katz, C., Webb, V., \& Schaefer, D. (2001). An assessment of the impact of quality-of-life policing on crime and disorder. Justice Quarterly, 18, 825-876. http://dx.doi.org $/ 10.1080 / 07418820100095111$

Klinger, D. A., \& Bridges, G. (1997). Measurement error in calls-for-service as an indicator of crime. Criminology, 35, 705-726. http//dx.doi.org/10.1111/j.1745-9125.1997.tb01236.x

Lilly, J. R., Cullen, F. T., \& Ball, R. A. (2011). Criminological theory: Context and 
consequences. Thousand Oaks, CA: Sage.

Lohr, K. (2006, July 19). Drugs and crime plague FEMA trailer park residents. Retrieved September, 10, 2010, from http//www.npr.org/templates/story/Story.php?storyId=5565424

Mazerolle, G. L., Ready, J., Terrill, W., \& Waring, E. (2000). Problem-oriented policing in public housing: The Jersey City evaluation. Justice Quarterly, 17, 129-159. http://dx.doi.org/10.1080/07418820000094501

McNulty, T. L., \& Holloway, S. R. (2000). Race, Crime, and Public Housing in Atlanta: Testing a Conditional Effect Hypothesis. Social Forces, 79, 707-729. http://dx.doi.org $/ 10.1093 / \mathrm{sf} / 79.2 .707$

Merton, R. (1938). Social Structure and Anomie. American Sociological Review, 3, 672-682.

Newman, O. (1972). Defensible space. New York: Macmillan.

Park, R., Burgess, E., \& McKenzie, R. (1925). The City. Chicago: University of Chicago Press. http://dx.doi.org/10.1177/000271622612400158

Popkin, D. J., Gwiasda, V. E., \& Olson, L. M. (2000). The hidden war: crime and the tragedy of public housing in Chicago. New Brunswick, NJ: Rutgers University Press.

Poyner, B., \& Webb, B. (1991). Crime Free Housing. Oxford, UK: Butterworth.

Reynolds, D. (2008, May 30). How to spot crime in a mobile home park. Retrieved September 10, 2010, from http://ezinearticles.com/?How- $\neg$ To- $\neg$ Spot- $\neg$ Crime- $\neg$ In - $\neg$ A--Mobile- $\neg$ Home- $\neg$ Park\&id=1214242

Roncek, D. W., Bell R., \& Francik, J. M. A. (1981). Housing projects and crime. Social Problems, 29, 151-166. http://dx.doi.org/10.1525/sp.1981.29.2.03a00060

Rose, L. (1988). "Rogues and vagabonds" - vagrant underlife in Britain 1815-1985. London: Routledge. http://dx.doi.org/10.5860/CHOICE.26-3421

Salamon, S., \& MacTavish, K. (2005). Quasi-homelessness among rural trailer-park households in the United States. In P. Cloke, \& P. Milbourne (Eds.), International Perspectives on Rural Homelessness. Routledge Press.

Sampson, R. J. (1985). Race and criminal violence: a demographically disaggregated analysis of urban homicide. Crime and Delinquency, 31, 47-82. http://dx.doi.org/10.1177 /0011128785031001004

Sampson, R. J. (1987). Urban black violence: the effect of male joblessness and family disruption. American Journal of Sociology, 93, 348-382. http///dx.doi.org/10.1086/228748

Sampson, R. J., \& Groves, W. B. (1989). Community structure and crime: testing social disorganization theory, American Journal of Sociology, 94, 774-802. http://dx.doi.org $/ 10.1086 / 229068$

Sampson, R. J., \& Wilson, W. J. (1995). Toward a theory of race, crime, and urban inequality. 


\section{Macrothink}

Issues in Social Science ISSN 2329-521X 2014, Vol. 2, No. 2

In J. Hagan, \& R. D. Peterson (Eds.), Crime and inequality (pp. 37-54). Stanford University Press.

Sampson, R. J., Raudenbush, S. W., \& Earls, F. (1997). Neighborhoods and violent crime: a multilevel study of collective efficacy. Science, 277, 918-924. http://dx.doi.org/ $10.1126 /$ science. 277.5328 .918

Shaw, C. R., \& McKay, H. D. (1969). Juvenile delinquency and urban areas. University of Chicago Press.

Sherman, L., \& Weisburd, D. (1995). General deterrent effects of police patrol on crime 'hotspots': a randomized controlled trial. Justice Quarterly 12, 626-648. http://dx.doi.org/10.1080/07418829500096221

Sherman, L., Gartin, P., \& Buerger, M. (1989). Hotspots of predatory crime: routine activities and the criminology of place. Criminology, 27, 27-55. http://dx.doi.org/10.1111 /j.1745-9125.1989.tb00862.x

U.S. Census Bureau. (2011). Profile of General Population and Housing Characteristics. Retrieved from http//factfinder2.census.gov

Weisburd, D., \& Greene, L. (1995). Policing drug hotspots: the jersey city drug market analysis experiment. Justice Quarterly, 12, 711-735. http://dx.doi.org/1080 /07418829500096261

William Brill and Associates. (1977). Victimization, Fear of Crime and Altered Behavior: A Profile of the Crime Problem in Four Housing Projects in Boston. Washington, DC: U.S. Department of Housing and Urban Development. 